\title{
Atrial Fibrillation, Cognitive Decline, and Dementia: an Epidemiologic Review
}

\author{
Mozhu Ding ${ }^{1} \cdot$ Chengxuan Qiu ${ }^{1,2}$
}

Published online: 7 July 2018

(C) The Author(s) 2018

\begin{abstract}
Purpose of Review Atrial fibrillation (AF) and dementia are both prevalent diseases in aging societies, which exert a great economic burden worldwide. Although a handful of epidemiologic studies have indicated that AF is independently associated with faster cognitive decline and a higher risk of dementia, there is still a lack of comprehensive understanding of the observed association. In this review, we summarize evidence from major epidemiologic studies concerning AF-related cognitive decline and dementia, the potential mechanisms underlying their association, and the cognitive benefits of treatment options.

Recent Findings A large majority of population-based longitudinal studies have consistently shown an independent association of AF with cognitive decline and dementia with varying effect sizes, depending on the age of the study population and the presence of clinical stroke. The underlying pathways linking AF to cognitive phenotypes may involve systemic inflammation, cerebral hypoperfusion, and cerebral small vessel disease and microemboli. However, current evidence is insufficient to support the potential benefits of AF treatment in reducing risk of cognitive decline and dementia.

Summary Current epidemiologic research suggests that AF contributes to cognitive decline and dementia, independent of a history of stroke. Further work is warranted to elucidate the potential mechanisms underlying this association, and more welldesigned studies are needed to explore the possible cognitive benefits of different therapeutic options in patients with AF.
\end{abstract}

Keywords Atrial fibrillation $\cdot$ Cognitive decline $\cdot$ Dementia $\cdot$ Pharmaceutical treatment $\cdot$ Epidemiology

\section{Introduction}

Atrial fibrillation (AF) is the most common sustained cardiac arrhythmia, characterized by uncoordinated atrial activation and ineffective atrial contraction. AF can be defined on electrocardiogram (ECG) as irregular RR intervals and absence of distinct $\mathrm{P}$ waves [1]. With a lifetime risk of around $25 \%$ in people aged 55 years and above [2, 3], AF predominantly affects older adults and represents a major clinical risk factor for heart failure, myocardial infarction, ischemic stroke, and mortality [4-6]. Since the 1990s, the prevalence, incidence,

This article is part of the Topical Collection on Cardiovascular Disease

Chengxuan Qiu

chengxuan.qiu@ki.se

1 Aging Research Center, Department of Neurobiology, Care Sciences and Society, Widerströmska Huset, Karolinska Institutet and Stockholm University, Tomtebodavägen 18A, 17165 Solna, Sweden

2 Department of Neurology, Shandong Provincial Hospital Affiliated with Shandong University, Jinan, Shandong, China and overall burden of AF have been continuously growing worldwide [7]; it was estimated that approximately 46.3 million people worldwide had AF in 2016, a $40 \%$ increase from 33.5 million in 2010 [7, 8].

Dementia is a disabling syndrome of the brain, characterized by a progressive deterioration of memory and other cognitive functions [9]. The number of people affected by dementia worldwide was estimated at 47 million in 2015, and each year around 7.7 million new cases were added into the pool [10]. The total global cost of dementia was estimated at US $\$ 818$ billion in 2015 and will rise above US\$1 trillion in 2018 [10]. Thus, dementia has been recognized by WHO, Alzheimer's Disease International, and the London G8 Dementia Summit as a global public health priority [11, 12]. In the past decade, AF has emerged as a potential risk factor for cognitive decline and dementia; however, there is still a lack of a conclusive understanding of the complex relationship between these two disorders. Knowledge gaps exist regarding the mechanisms of AF-related cognitive consequences beyond aging and stroke, and the optimal way to prevent cognitive decline and dementia in patients with $\mathrm{AF}$ 
remains to be established [13••]. Understanding the pathophysiological mechanisms behind this association and exploring the cognitive benefits of different treatment options in patients with AF may help reduce the massive burden of both $\mathrm{AF}$ and dementia on individuals and health care systems.

Therefore, in this review, we aim to summarize the current epidemiologic literature on (1) the association of $\mathrm{AF}$ with cognitive decline and dementia, (2) plausible mechanisms underlying this association, and (3) the potential cognitive benefit of therapeutic options in patients with $\mathrm{AF}$.

\section{Association of Atrial Fibrillation with Cognitive Decline and Dementia: Epidemiologic Evidence}

A number of well-established population-based cohort studies have demonstrated an association between $\mathrm{AF}$ and increased risk of cognitive decline or dementia (Table 1) [14, 15••, 16••, $17 \bullet \bullet, 18,19,20 \bullet \cdot, 21 \bullet \cdot, 22-27]$, especially among youngerold people. For instance, the UK Whitehall II study showed that in people aged 45-69 years, AF is significantly associated with higher risk of incident dementia ( $\mathrm{HR}=1.87,95 \% \mathrm{CI}$ 1.37-2.55) and that longer exposure to AF is associated with faster cognitive decline compared with AF-free adults [16••]; taking into account incident stroke did not significantly alter the results. In the Atherosclerosis Risk in Communities (ARIC) Study, data were available from 12,515 participants (mean age 56.9 years) who were followed up for over 20 years. This study reported that incident AF was associated with faster global cognitive decline and higher risk of dementia after adjusting for cardiovascular diseases including ischemic stroke [15••]. The US Cardiovascular Health Study demonstrated that, in the absence of clinical stroke, the cognitive function declined faster in patients experiencing incident $\mathrm{AF}$ compared to people with no prior AF [19]. In the Rotterdam study, AF is associated with an elevated risk of incident dementia only among people younger than 67 years $(\mathrm{HR}=1.81$, 95\% CI 1.11-2.94) [17••]. Similarly, the US Intermountain Heart Collaborative Study showed that the highest risk of dementia associated with AF was seen in people younger than 70 years [24]. Concerning dementia subtypes, in a large-scale population-based study, we found that AF is associated with increased risk of vascular and mixed dementia but not with Alzheimer's disease (AD). Among the oldest-old (e.g., age $\geq$ 80 years), there is yet not enough evidence from epidemiologic studies to support an association of AF with cognitive decline and dementia, and more data from population-based studies are needed to fully elucidate this association in the oldest-old population, as reported by a recent review of studies carried out in subjects $\geq 80$ years [28•].
Several systematic reviews and meta-analyses have been conducted to assess the relationship between AF and dementia. For example, a systematic review comprising data from 15 longitudinal population-based studies that cover 46,637 participants reported that the association between AF and incident dementia is evident mainly in studies solely focusing on patients with stroke (HR $=2.4,95 \%$ CI 1.7-3.5), while their association remained marginal in studies with broader populations ( $\mathrm{HR}=1.6,95 \%$ CI 1.0-2.7) [29]. Another metaanalysis including 8 longitudinal studies with 77,668 patients not suffering from acute stroke at baseline indicated that $\mathrm{AF}$ was independently associated with an increased risk of dementia (HR $=1.4,95 \%$ CI 1.2-1.7) [30]. A larger systematic review including 21 studies with either cross-sectional or longitudinal designs demonstrated that $\mathrm{AF}$ is associated with more than a twofold increased risk of dementia or cognitive impairment after stroke (HR $=2.7,95 \%$ CI 1.8-4.0), and the increased risk, although less strong, remained significant when restricting to studies that only included participants without a history of stroke (HR $=1.4,95 \%$ CI 1.1-1.7) [31].

Taken together, current evidence from populationbased longitudinal studies and systematic reviews suggests an independent association of AF with cognitive decline and dementia, especially among young-old people, irrespective of a history of stroke. Further understanding the potential pathological mechanisms behind this association may help develop proper preventive and therapeutic interventions to counteract the risk of cognitive consequences resulting from $\mathrm{AF}$.

\section{Association of Atrial Fibrillation with Cognitive Decline and Dementia: Potential Mechanisms}

It has been argued that $\mathrm{AF}$ and dementia may merely develop alongside each other as a result of the aging process and shared precipitating conditions. Indeed, AF, cognitive decline, and dementia share several modifiable risk factors, such as lifestyle factors (e.g., physical inactivity, smoking, and excessive alcohol consumption), cardiometabolic risk factors (e.g., obesity, hypertension, diabetes, and high cholesterol), and cardiovascular disorders (e.g., atherosclerosis, heart failure, and coronary heart disease) [9, 32, 33]. Although major clinical disorders have been adjusted for in the majority of studies investigating the association between $\mathrm{AF}$ and cognitive decline or dementia, imperfect measurements of these disorders and other unknown risk factors may still confound the association. Beyond shared risk factors, AF may accelerate cognitive decline and increase the risk of dementia through different pathways such as cerebral hypoperfusion, systemic inflammation, and cerebral small vessel diseases (SVDs) (Fig. 1) [32, 34-36]. 
Table 1 A summary of the main population-based longitudinal studies assessing the association between atrial fibrillation and risk of cognitive decline or dementia

\begin{tabular}{|c|c|c|c|c|}
\hline Study, country & Study population & $\begin{array}{l}\text { Assessment of } \\
\text { atrial fibrillation }\end{array}$ & $\begin{array}{l}\text { Assessment of cognitive } \\
\text { outcomes }\end{array}$ & Main findings \\
\hline $\begin{array}{l}\text { Nishtala et al. } \\
\text { [14], USA }\end{array}$ & $\begin{array}{l}\text { Framingham Heart Study original and } \\
\text { offspring cohort; } 3 \text { - or } 6 \text {-year } \\
\text { follow-up; mean age } 83 \text { for the original } \\
\text { and } 68 \text { for the offspring cohort; } \\
N=2628\end{array}$ & $\begin{array}{l}\text { Self-reports, } \\
\text { ECG, and } \\
\text { medical } \\
\text { registers }\end{array}$ & $\begin{array}{l}\text { Cognitive function: a } \\
\text { neuropsychological } \\
\text { battery on major } \\
\text { cognitive domains }\end{array}$ & $\begin{array}{l}\text { - Prevalent } \mathrm{AF} \text { is associated with faster } \\
\text { decline in executive function } \\
(\beta \text { coefficient }=-0.31 ; 95 \% \\
\text { CI }-0.37,-0.25)\end{array}$ \\
\hline $\begin{array}{l}\text { Chen et al. } \\
{[15 \bullet \bullet] \text { USA }}\end{array}$ & $\begin{array}{l}\text { Atherosclerosis Risk in Communities } \\
\text { Study; } 20 \text {-year follow-up; mean age } \\
56.9 \text { at baseline; } N=12,515\end{array}$ & $\begin{array}{l}\text { ECG and ICD-9 } \\
\text { codes (427.31 } \\
\text { and } 427.32)\end{array}$ & $\begin{array}{l}\text { Cognitive function: } 3 \\
\text { neuropsychological tests } \\
\text { Dementia: diagnostic } \\
\text { algorithm and ICD-9 } \\
\text { codes }\end{array}$ & $\begin{array}{l}\text { - } \mathrm{AF} \text { is associated with faster global } \\
\text { cognitive decline (difference in } Z \\
\text { score }=0.12,95 \% \text { CI } 0.03-0.23) \\
\text { - } \mathrm{AF} \text { is associated with incident dementia } \\
\quad(\mathrm{HR}=1.31,95 \% \mathrm{CI}=1.11-1.55)\end{array}$ \\
\hline $\begin{array}{l}\text { Singh-Manoux } \\
\text { et al. }[16 \bullet \bullet \\
\text { UK }\end{array}$ & $\begin{array}{l}\text { Whitehall II Study; 26.6-year follow-up; } \\
\text { age range } 45-69 \text { at baseline; } \\
N=10,217\end{array}$ & $\begin{array}{l}\text { 12-lead ECG and } \\
\text { ICD-9/10 } \\
\text { codes }(437.3 \\
\text { and I48) }\end{array}$ & $\begin{array}{l}\text { Cognitive function: a } \\
\text { cognitive test battery } \\
\text { (memory, reasoning, and } \\
\text { verbal fluency) } \\
\text { Dementia: ICD-10 codes }\end{array}$ & $\begin{array}{l}\text { - Longer exposure to } \mathrm{AF} \text { is associated } \\
\text { with faster cognitive decline ( } p \text { for } \\
\text { trend }=0.01) \\
\text { - AF is associated with incident dementia } \\
(\mathrm{HR}=1.87,95 \% \mathrm{CI} 1.37-2.55) \\
\text { - Stroke does not explain these } \\
\text { associations }\end{array}$ \\
\hline $\begin{array}{c}\text { de Bruijn et al. } \\
{[17 \bullet \bullet] \text {, The }} \\
\text { Netherlands }\end{array}$ & $\begin{array}{l}\text { Rotterdam Study; } 21 \text {-year follow-up; age } \\
\text { 55+ at baseline; } N=6514\end{array}$ & $\begin{array}{l}\text { ECG, physician } \\
\text { diagnosis, and } \\
\text { medical } \\
\text { registers }\end{array}$ & $\begin{array}{l}\text { Dementia: DSM-III-R } \\
\text { criteria }\end{array}$ & $\begin{array}{l}\text { - Incident } \mathrm{AF} \text { is related to dementia only } \\
\text { in people }<67 \text { years }(\mathrm{HR}=1.81,95 \% \\
\text { CI } 1.11-2.94) \\
\text { - Duration of AF is associated with } \\
\text { dementia risk only in people } \\
<67 \text { years }(p \text { for trend }=0.003)\end{array}$ \\
\hline $\begin{array}{l}\text { Rusanen et al. } \\
\text { [18], Finland }\end{array}$ & $\begin{array}{l}\text { CAIDE study; mean 7.8-year follow-up; } \\
\quad \text { age range } 65-79 ; N=1510\end{array}$ & Medical registers & Dementia: DSM-IV criteria & $\begin{array}{l}\text { - Prevalent AF is associated with } \\
\text { dementia (HR =2.61, 95\% CI } \\
1.05-6.47) \text { and Alzheimer's disease } \\
\text { (HR=2.54, 95\% CI } 1.04-6.16) \text {; the } \\
\text { association is evident only in APOE } \\
\text { non-carriers }\end{array}$ \\
\hline $\begin{array}{c}\text { Thacker et al. } \\
\text { [19], USA }\end{array}$ & $\begin{array}{l}\text { Community-dwelling people; mean } \\
\text { 7-year follow-up; age } 73 \text { at baseline; } \\
N=5150\end{array}$ & $\begin{array}{l}\text { ECG, ICD-9 } \\
\text { codes }\end{array}$ & $\begin{array}{l}\text { Cognitive function: } \\
\text { modified MMSE } \\
\text { (3MSE) and Digit } \\
\text { Symbol Substitution } \\
\text { Test }\end{array}$ & $\begin{array}{l}\text { - Incident } \mathrm{AF} \text { is associated with } \\
\text { accelerated 5-year cognitive decline } \\
\text { for age } 70,75,80 \text {, and } 85 \text { years }\end{array}$ \\
\hline $\begin{array}{l}\text { Haring et al. } \\
\text { [20], USA }\end{array}$ & $\begin{array}{l}\text { RCTs of postmenopausal women; } \\
\text { median } 8.6 \text {-year follow-up; age } 60+\text { at } \\
\text { baseline; } N=7479\end{array}$ & $\begin{array}{l}\text { Self-reports or } \\
\text { physical } \\
\text { measure }\end{array}$ & $\begin{array}{l}\text { MCI and probable } \\
\text { dementia: DSM-IV } \\
\text { criteria }\end{array}$ & $\begin{array}{l}\text { - Prevalent } \mathrm{AF} \text { is not related to probable } \\
\text { dementia }(\mathrm{HR}=1.12,95 \% \mathrm{CI} \\
0.59-2.14) \\
\text { - Prevalent AF is not associated with mild } \\
\text { cognitive impairment (HR }=1.46, \\
\text { 95\% CI } 0.90-2.37)\end{array}$ \\
\hline $\begin{array}{l}\text { Marzona et al. } \\
\text { [21], } 40 \\
\text { countries }\end{array}$ & $\begin{array}{l}\text { Two RCTs of patients with CVD or } \\
\text { diabetes; median follow-up } \\
56 \text { months; mean age } 66.5 \text { at baseline; } \\
N=31,506\end{array}$ & 12-lead ECG & $\begin{array}{l}\text { Cognitive function: MMSE } \\
\text { Dementia: new dementia } \\
\text { diagnosis, reported } \\
\text { severe cognitive } \\
\text { impairment, or MMSE } \\
\leq 23\end{array}$ & $\begin{array}{l}\text { - Prevalent and incident } \mathrm{AF} \text { is associated } \\
\text { with } \geq 3 \text { points decline in MMSE } \\
\text { during the follow-up }(\mathrm{HR}=1.14,95 \% \\
\text { CI } 1.03-1.26) \\
\text { - Prevalent and incident AF is associated } \\
\text { with dementia (HR }=1.30,95 \% \mathrm{CI} \\
1.14-1.49)\end{array}$ \\
\hline $\begin{array}{l}\text { Dublin et al. } \\
\text { [22], USA }\end{array}$ & $\begin{array}{l}\text { Community-dwelling people; mean } \\
6.8 \text {-year follow-up; mean age } 74.3 \text { at } \\
\text { baseline; } N=3045\end{array}$ & $\begin{array}{l}\text { At least two } \\
\text { documented } \\
\text { ICD-9 codes } \\
\text { within } \\
12 \text { months }\end{array}$ & $\begin{array}{l}\text { Dementia: DSM-IV criteria } \\
\text { AD: NINCDS-ADRDA } \\
\text { criteria }\end{array}$ & $\begin{array}{l}\text { - Prevalent AF is associated with } \\
\text { dementia }(\mathrm{HR}=1.38,95 \% \mathrm{CI} \\
1.10-1.73) \\
\text { - Prevalent } \mathrm{AF} \text { is associated with } \mathrm{AD} \\
(\mathrm{HR}=1.50,95 \% \mathrm{CI} 1.16-1.94)\end{array}$ \\
\hline $\begin{array}{l}\text { Marengoni et } \\
\text { al. [23], } \\
\text { Sweden }\end{array}$ & $\begin{array}{l}\text { Kungsholmen Project; } 6 \text {-year follow-up; } \\
\text { age } 75+\text { at baseline; } N=685\end{array}$ & $\begin{array}{l}\text { Physician } \\
\text { diagnosis, } \\
\text { medical } \\
\text { records, drug } \\
\text { use, and ICD-9 } \\
\text { codes }\end{array}$ & $\begin{array}{l}\text { Dementia: DSM-III-R } \\
\text { criteria }\end{array}$ & $\begin{array}{l}\text { - No association between } \mathrm{AF} \text { and } \\
\text { dementia }(\mathrm{HR}=0.9,95 \% \mathrm{CI} 0.5-1.7) \\
\text { or } \mathrm{AD}(\mathrm{HR}=0.8,95 \% \text { CI } 0.4-1.5)\end{array}$ \\
\hline
\end{tabular}


Table 1 (continued)

\begin{tabular}{|c|c|c|c|c|}
\hline Study, country & Study population & $\begin{array}{l}\text { Assessment of } \\
\text { atrial fibrillation }\end{array}$ & $\begin{array}{l}\text { Assessment of cognitive } \\
\text { outcomes }\end{array}$ & Main findings \\
\hline $\begin{array}{l}\text { Bunch et al. } \\
\text { [24], USA }\end{array}$ & $\begin{array}{l}\text { Health care patients; mean } 5 \text {-year } \\
\text { follow-up; mean age } 60.6 \text { at baseline; } \\
\quad N=37,025\end{array}$ & $\begin{array}{l}\text { ECG and ICD-9 } \\
\text { codes }\end{array}$ & Dementia: ICD-9 codes & $\begin{array}{l}\text { - Prevalent } \mathrm{AF} \text { is associated with vascular } \\
\text { dementia }(\mathrm{HR}=1.73, p=0.001) \\
\text { senile dementia }(\mathrm{HR}=1.39, \\
p=0.005), \text { and non-specific dementia } \\
\text { (HR }=1.44, p<0.001) ; \text { highest risk } \\
\text { was in younger group }(<70 \text { years })\end{array}$ \\
\hline $\begin{array}{l}\text { Peters et al. } \\
\text { [25], UK }\end{array}$ & $\begin{array}{l}\text { RCT of hypertensive patients; mean } \\
\text { 2-year follow-up; age } 80+\text { at baseline; } \\
\quad N=3336\end{array}$ & ECG & $\begin{array}{l}\text { Cognitive decline: decrease } \\
\text { to MMSE }<24 \text { or by }>3 \\
\text { point annually } \\
\text { Dementia: DSM-IV } \\
\text { criteria, a CT scan, and } \\
\text { modified ischemic score }\end{array}$ & $\begin{array}{l}\cdot \text { No association between prevalent } \mathrm{AF} \\
\text { and dementia }(\mathrm{HR}=1.03,95 \% \mathrm{CI} \\
0.62-1.72) \\
\cdot \text { No association between prevalent } \mathrm{AF} \\
\text { and cognitive decline }(\mathrm{HR}=1.08,95 \% \\
\text { CI } 0.80-1.46) \\
\text { - No association between prevalent AF } \\
\text { and annual change of MMSE }(\beta \\
\text { coefficient }=-0.26 ; 95 \% \mathrm{CI}-0.66, \\
0.13)\end{array}$ \\
\hline $\begin{array}{l}\text { Rastas et al. } \\
\text { [26], Finland }\end{array}$ & $\begin{array}{l}\text { Community-dwelling people; } 9 \text {-year } \\
\text { follow-up; age } 85+\text { at baseline; } \\
N=553\end{array}$ & $\begin{array}{l}\text { 12-lead ECG or } \\
\text { 1-h Holter } \\
\text { ECG; health } \\
\text { records }\end{array}$ & $\begin{array}{l}\text { Dementia: DSM-III-R } \\
\text { criteria }\end{array}$ & $\begin{array}{l}\text { - No association between prevalent } \mathrm{AF} \\
\text { and dementia }\end{array}$ \\
\hline $\begin{array}{l}\text { Tilvis et al. } \\
\text { [27], Finland }\end{array}$ & $\begin{array}{l}\text { Community-dwelling people; } 10 \text {-year } \\
\text { follow-up; age } 75,80 \text {, and } 85 \text { at } \\
\text { baseline; } N=650\end{array}$ & $\begin{array}{l}\text { Clinical } \\
\quad \text { examinations }\end{array}$ & $\begin{array}{l}\text { Cognitive decline: increase } \\
\text { in Clinical Dementia } \\
\text { Rating class or at least } 4 \\
\text { point decrease in MMSE }\end{array}$ & $\begin{array}{l}\text { - } \mathrm{AF} \text { is associated with 5-year cognitive } \\
\text { decline }(\mathrm{RR}=2.88,95 \% \mathrm{CI} \\
1.26-6.06)\end{array}$ \\
\hline
\end{tabular}

$A F$ atrial fibrillation, $E C G$ electrocardiogram, $H R$ hazard ratio, $C I$ confidence interval, $R R$ relative risk, $O R$ odds ratio, $I C D-9 / 10$ International Statistical Classification of Diseases and Related Health Problems, 9th Revision/10th revision, DSM-III-R Diagnostic and Statistical Manual of Mental Disorders, 3rd Edition, Revised, DSM-IV Diagnostic and Statistical Manual of Mental Disorders, 4th Edition, NINCDS-ADRDA National Institute of Neurological and Communicative Disorders and Stroke-Alzheimer's Disease and Related Disorders Association, $M C I$ mild cognitive impairment, CAIDE Cardiovascular Risk Factors, Aging and Dementia. MMSE Mini-Mental State Examination, $R C T$ randomized control trial, $C V D$ cardiovascular disease, CT computed tomography

\section{Cerebral Hypoperfusion}

Persistent AF reduces cardiac output and may lead to chronic cerebral hypoperfusion and hypoxia, which may impair the clearance and promote the accumulation of amyloid-beta peptides in cerebral vessels, thus leading to cerebral amyloid angiopathy and contributing to the onset of Alzheimer's disease (AD) [37-39]. However, this hypothesis has been investigated by very few studies, among which one study examined the cognitive function and cerebral blood flow velocity in the major brain arteries in 187 patients with heart failure, out of which $32 \%$ had a history of AF [40]. This cross-sectional study showed a greater reduction in
Fig. 1 Potential pathophysiological pathways linking atrial fibrillation with cognitive decline, mild cognitive impairment (MCI), and dementia

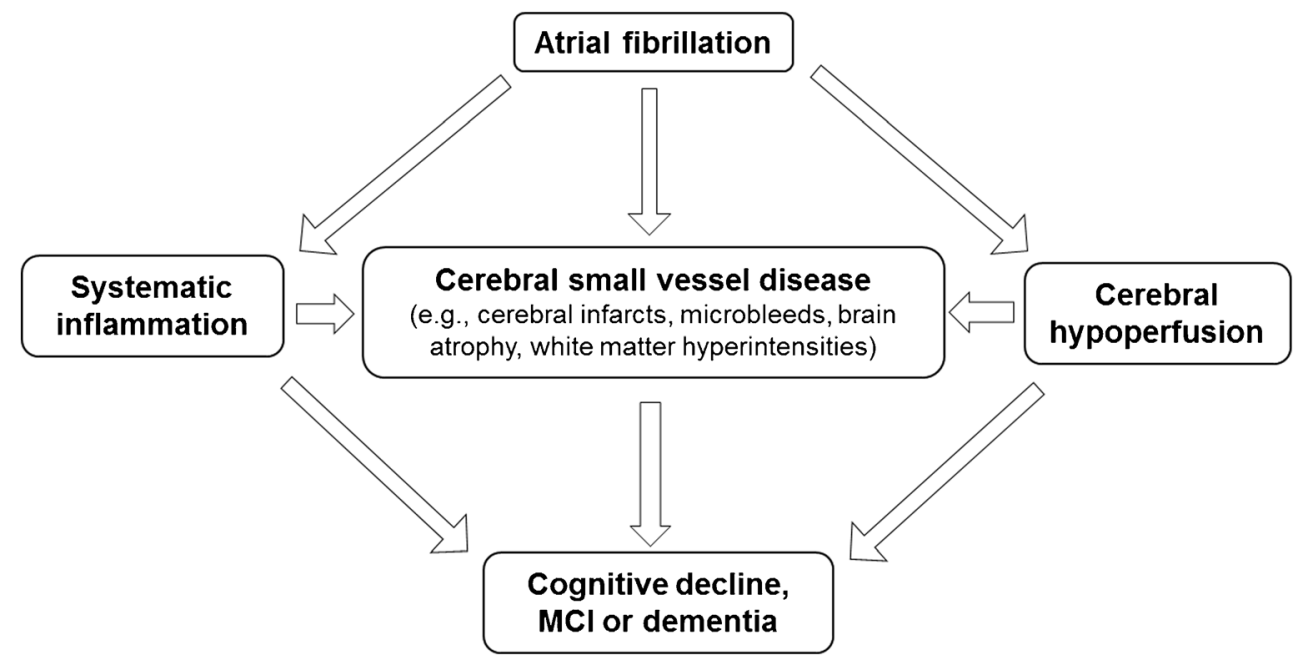


cerebral blood flow and worse cognitive performance among heart failure patients with $\mathrm{AF}$ than those without $\mathrm{AF}$, as well as an association between decreased cerebral perfusion and worse cognitive function. However, it has also been argued in a recent review that the cerebral hypoperfusion hypothesis cannot explain the majority of dementia cases since cerebral autoregulation is expected to maintain cerebral blood flow within a wide blood pressure range and evidence is lacking to support that cerebral autoregulation is impaired in patients with AF [32]. Further studies are needed to investigate whether and how cerebral hypoperfusion plays a role in the association between $\mathrm{AF}$ and cognitive dysfunction.

\section{Systemic Inflammation}

Several comprehensive reviews have summarized the potential pathways linking the initiation and perpetuation of AF to systemic inflammation status, including but not limited to increased level of C-reactive protein, tumor necrosis factor- $\alpha$, interleukin (IL)-2, IL-6, and IL-8, and monocyte chemoattractant protein-1 $[41,42]$. Previous studies have shown that these inflammation markers are associated with hypercoagulation, endothelial dysfunction, and increased platelet activation, thus contributing to AF-related thromboembolism [43, 44].

Given the high systemic inflammation status and prothrombotic environment in $\mathrm{AF}$, it is possible that patients with $\mathrm{AF}$ are more susceptible to blood-brain barrier damage and cerebral microstructural changes, leading to cognitive decline and dementia [45]. It has been shown that a higher level of highsensitivity C-reactive protein is associated with worse executive functioning and more microvascular damage in the white matter [46], as well as an elevated risk of all dementia subtypes independently of cardiovascular risk factors and related diseases [47]. So far, the mediating role of inflammation in the association of $\mathrm{AF}$ with cognitive decline and dementia remains to be investigated.

\section{Cerebral Small Vessel Diseases and Microemboli}

Cerebral SVDs refer to a group of pathological processes that affect the small arteries, arterioles, venules, and capillaries of the brain $[48,49]$. Cerebral SVDs, as detected using brain imaging techniques such as magnetic resonance imaging, are subcortical infarcts, lacunes, white matter hyperintensities (WMH), brain atrophy, cerebral microbleeds (CMBs), and perivascular spaces [50]. Importantly, recent epidemiologic studies have shown that cerebral SVDs are a leading cause of cognitive decline and functional loss in the elderly [48, 51], and have been hypothesized to play a key role in the association of AF with cognitive decline and dementia [35].

Although cerebral infarction manifested as a stroke is the most feared consequence of $\mathrm{AF}$, subclinical silent cerebral infarcts (SCIs) are found in up to $90 \%$ of people with AF [35]. A recent meta-analysis showed that $\mathrm{AF}$ was associated with more than a twofold increased risk of any SCIs, independent of AF subtypes [52], and presence of SCIs is associated with two to threefold increased risk of both symptomatic stroke and dementia $[53,54]$. Consequently, a higher proportion of SCIs in patients with $\mathrm{AF}$ may put them at greater risk of cognitive decline and dementia. The ARIC study, in which 935 stroke-free participants were recruited and followed up for 10 years, showed that incident $\mathrm{AF}$ was associated with greater decline in word fluency among people who had prevalent SCIs; among those without prevalent SCIs, incident AF was not associated with cognitive decline [55]. These findings support the hypothesis that, in the absence of overt stroke, the association between $\mathrm{AF}$ and cognitive decline may be, at least partly, explained by SCIs.

On the other hand, the association between $\mathrm{AF}$ and $\mathrm{WMH}$ is less clear. For instance, one retrospective cohort study of 234 patients with stroke showed that $\mathrm{AF}$ was associated with the presence of anterior subcortical WMH [56•]. Similarly, another hospital-based study demonstrated that deep and subcortical $\mathrm{WMH}$ grade was higher among patients with $\mathrm{AF}$ compared to matched controls [57]. On the contrary, the Framingham Offspring Study found no evidence of an association between $\mathrm{AF}$ and WMH volumes over 6 years of follow-up after adjusting for several vascular risk factors and cardiovascular diseases [58]. Indeed, it has been suggested that brain ischemia resulting from low cardiac output and cerebral hypoperfusion may lead to $\mathrm{WMH}$ and that chronic SCIs could also convert into WMH $[59,60]$. Yet whether and to what extent WMH play a role in the association of $\mathrm{AF}$ with cognitive decline and dementia remains to be further investigated.

$\mathrm{AF}$ appears to be also associated with loss of brain volumes, which in turn leads to cognitive dysfunction. The underlying mechanisms may include hypoperfusion of gray matter, systemic inflammation, chronic micro-embolisms, and CMBs [61-63]. The cross-sectional study in Germany showed that AF is associated with reduced hippocampal volume, a hallmark in $\mathrm{AD}$ [64]. The population-based AGES-Reykjavik Study found that AF was associated with lower total brain, gray matter, and white matter volumes, especially among patients with longer duration of AF, but the association of AF with WMH volume was less evident [65]. The Framingham Offspring study demonstrated that $\mathrm{AF}$ was associated with lower frontal brain volume even after adjusting for vascular risk factors and APOE $\varepsilon 4$ status [58].

As the brain ages, cerebral small vessels are susceptible to microbleeds partly due to cerebral amyloid angiopathy, especially when using anticoagulant treatment. The occurrence of CMBs increases with advancing age and is more common among $\mathrm{AD}$ and stroke patients [63]. A clinic-based study showed that $\mathrm{CMBs}$ were more common in patients with $\mathrm{AF}$ than those without [66]. Controversies exist regarding anticoagulation in older AF patients, since CMBs and subsequent intracranial hemorrhage are the most feared complications of anticoagulant treatment [67]. Interestingly, a clinicalbased study of 550 patients with ischemic stroke and AF 
showed that a higher $\mathrm{CHADS}_{2}$ score (a score contains major clinical risk factors for stroke that is scored 1 point for each of chronic heart failure, hypertension, age $\geq 75$ years, and diabetes and 2 points for ischemic stroke or transient ischemic attacks) was strongly correlated with the number of CMBs, and that the presence of CMBs was independently associated with the development of intracranial hemorrhage [68]. Furthermore, the Rotterdam study found that the presence of CMBs was associated with faster cognitive decline and higher risk of dementia and $\mathrm{AD}[69]$.

Taken together, current evidence suggests an important role of cerebral SVDs in the association between AF and cognitive dysfunction.

\section{Do Treatment Options in Patients with Atrial Fibrillation Prevent Cognitive Decline or Dementia?}

\section{Anticoagulant Treatment}

Oral anticoagulant drugs remain the first-line medication for the prevention of ischemic stroke in patients with AF [70]. Given that both macro-embolic (e.g., clinical stroke) and micro-embolic events (e.g., SCIs) related to AF may contribute to cognitive decline and the onset of dementia, it is likely that anticoagulant treatment could benefit cognitive function and lower the risk of dementia in AF patients by reducing cerebral infarct burden [71-73]. Warfarin is the most commonly prescribed anticoagulant agent for the prevention of AF-related stroke, even after the release of novel oral anticoagulant drugs (NOACs) [74]. Although a systematic review did not demonstrate an association between use of warfarin and risk of dementia in AF patients [75•], a few recent studies did show a trend toward a protective effect of warfarin therapy on cognitive outcomes in patients with AF $[76 \bullet \bullet, 77 \bullet, 78 \bullet$, $79^{\circ}$ ]. A retrospective study of all patients diagnosed with $\mathrm{AF}$ from 2006 to 2014 in the Swedish patient register reported that patients treated with anticoagulants had a $29 \%$ lower risk of dementia than those without anticoagulant treatment [76••]. Another community-based cohort study of patients with incident $\mathrm{AF}$ also demonstrated that warfarin therapy was associated with a $20 \%$ reduction in dementia risk over 5 years of follow-up [77•]. What confounds the interpretation of the effect of warfarin on dementia risk is that cognitive deficits may negatively influence the safety and thus the prescription decision of anticoagulant therapy in patients with AF. Furthermore, previous studies merely focus on the presence or absence of anticoagulant therapy and lack data on the quality of anticoagulation control, which is of major importance among older adults. It was reported that cognitive dysfunction was related to lower percentage time in therapeutic range (TTR) in older AF patients taking warfarin [80], and that decreasing percentage of TTR was associated with an increased risk of dementia [81]. It appears that both underanticoagulation (i.e., international normalized ratio (INR) < 2) and over-anticoagulation (i.e., INR $>3$ ) are associated with higher risk of dementia [81], probably due to cumulative brain injury from cerebral infarcts and microbleeds [34].

Although evidence is scarce regarding the effect of NOAC therapy on cognitive decline or dementia in patients with $\mathrm{AF}$, it is plausible that use of NOACs could be associated with lower dementia risk compared to warfarin. In randomizedcontrolled clinical trials, NOACs have shown similar efficacy as warfarin with regard to prevention of stroke and are associated with lower rates of intracranial hemorrhage and death in patients with $\mathrm{AF}[82,83]$. Two retrospective register-based studies have recently indicated that use of NOACs was associated with a lower risk of dementia compared to warfarin in patients with AF $[76 \bullet \bullet, 78 \bullet]$. Large longitudinal studies with longer follow-up time are needed to clarify the effect of NOACs on cognitive function, and currently several randomized-controlled clinical trials focusing on cognitive outcomes in patients with AF have been initiated [32].

\section{Other Therapies}

Low-dose antiplatelet drugs, such as aspirin, are often prescribed for the prevention of cardiovascular events in people at cardiovascular risk because of its antithrombotic properties [84]. However, evidence of effective prevention of stroke with antiplatelet drugs is weak in AF patients, with a potential for harm (e.g., increased risk of major bleeding or intracranial hemorrhage) [85]. Therefore, current international consensus guidelines recommended that use of antiplatelet drugs in AF patients should be limited, especially in older patients with AF [70]. In addition, previous studies have failed to show a protective effect of antiplatelet drugs on cognitive function in old age. For instance, a recent systematic review and metaanalysis that included 8 observational and interventional studies and 36,196 cognitively intact participants at baseline showed that chronic use of low-dose aspirin was not associated with global cognitive function, cognitive impairment, or the onset of dementia [86].

Since systemic inflammation has been proposed to be one of the potential mechanisms underlying the link between AF and cognitive dysfunction, it is likely that anti-inflammatory therapy may preserve cognitive function in patients with AF. Statins are now widely accepted to have anti-inflammatory properties, in addition to a lipid-lowering effect [87]. One register-based study in Taiwan reported a $20 \%$ decreased risk of incident non-vascular dementia in 51,253 patients with $\mathrm{AF}$ who received statin treatment compared to those who were not prescribed statin therapy [88•]. Another study showed that among older patients with AF, intensive lipid-lowering therapy with atorvastatin and ezetimibe was associated with less 
amygdala and hippocampal atrophy compared to placebo [89]. Nevertheless, these results need to be further confirmed in larger longitudinal studies.

With regard to rate and rhythm-control strategies, analysis of a subsample of the Atrial fibrillation Follow-up Investigation of Rhythm Management (AFFIRM) study showed no differences in global cognitive function between the rate-control and rhythm-control group at 2-month and yearly follow-up visits [90]. The Intermountain Atrial Fibrillation Study including 4212 patients who underwent catheter ablation for AF showed that $0.2 \%$ of the AF ablation patients developed $\mathrm{AD}$ after 3 years of follow-up compared to $0.9 \%$ in unoperated $\mathrm{AF}$ patients and $0.5 \%$ in patients without $\mathrm{AF}(p<0.001)$ [91]. Similarly, differences were also observed for other dementia subtypes. These findings suggest that rhythm-control strategy might potentially suppress hypoperfusion-induced $\mathrm{AD}$ pathology [39].

Taken together, chronic use of low-dose antiplatelet drugs does not demonstrate a protective effect on cognitive function and is not recommended in patients with $\mathrm{AF}$ for stroke prevention for maintaining cognitive function unless anticoagulant drugs are contraindicated. Evidence is still sparse regarding whether anti-inflammatory treatment and rhythm- and rate-control therapy can truly preserve cognitive function and reduce the risk of dementia in patients with $\mathrm{AF}$, and large longitudinal studies in more controlled settings are needed. In addition to pharmaceutical treatment, a recent expert consensus has recommended that general health maintenance and appropriate management of multiple risk factors and concomitant conditions related to AF (e.g., heart failure, hypertension, obesity, diabetes, and sleep apnoea) may decrease the risk of both AF and stroke, with a putative beneficial effect on cognitive function $[13 \bullet \bullet]$.

\section{Conclusion and Future Directions}

$\mathrm{AF}$ and dementia both affect predominantly the older population and exert a great economic and societal burden on aging societies. Numerous epidemiologic studies have shown an association of AF with an increased risk of cognitive decline and dementia with varying effect sizes, depending on the age of the study population and the presence of clinical stroke. Cerebral hypoperfusion, systemic inflammation, and cerebral SVDs are the major potential mechanisms underlying this association, and it is likely that these pathways work together to confer an increased risk of dementia in patients with AF. Efforts have been made to investigate whether different treatment strategies may counteract the risk of cognitive decline and dementia owing to AF; however, evidence is still sparse in this area. Highquality population-based longitudinal studies and randomizedcontrolled clinical trials are needed to explore different treatment options to prevent or delay cognitive decline and the onset of dementia in patients with AF.

Funding M.D. was supported in part by a grant from China Scholarship Council (no. 201507930005) and by grants from Konung Gustaf V:s och Drottning Victorias Frimurarestiftelse and Lindhés Foundation (LA20150440), Gamla Tjänarinnor (2017-00519), and the National Graduate School on Ageing and Health (SWEAH). C.Q. received grants from the Taishan Scholar Program of Shandong Province, China, and from the Swedish Research Council (grants no.: 2015-02531, 2017-00740, and 2017-05819), the Swedish Research Council for Health, Working Life and Welfare (grant no.: 2014-01382), and the Karolinska Institutet, Stockholm, Sweden.

\section{Compliance with Ethical Standards}

Conflict of Interest The authors declare no conflicts of interest.

Human and Animal Rights and Informed Consent This article does not contain any studies with human or animal subjects performed by any of the authors.

Open Access This article is distributed under the terms of the Creative Commons Attribution 4.0 International License (http:// creativecommons.org/licenses/by/4.0/), which permits unrestricted use, distribution, and reproduction in any medium, provided you give appropriate credit to the original author(s) and the source, provide a link to the Creative Commons license, and indicate if changes were made.

\section{References}

Papers of particular interest, published recently, have been highlighted as:

- Of importance

•• Of major Importance

1. Camm AJ, Kirchhof P, Lip GYH, Schotten U, Savelieva I, Ernst S, et al. Guidelines for the management of atrial fibrillation: the task force for the management of atrial fibrillation of the European Society of Cardiology (ESC). Eur Heart J. 2010;31:2369-429.

2. Lloyd-Jones DM, Wang TJ, Leip EP, Larson MG, Levy D, Vasan RS, et al. Lifetime risk for development of atrial fibrillation: the Framingham Heart Study. Circulation. 2004;110:1042-6.

3. Heeringa J, van der Kuip DAM, Hofman A, Kors JA, van Herpen G, Stricker BHC, et al. Prevalence, incidence and lifetime risk of atrial fibrillation: the Rotterdam Study. Eur Heart J. 2006;27:94953.

4. Wang TJ, Larson MG, Levy D, Vasan RS, Leip EP, Wolf PA, et al. Temporal relations of atrial ribrillation and congestive heart failure and their joint influence on mortality: the Framingham Heart Study. Circulation. 2003;107:2920-5.

5. Wolf PA, Abbott RD, Kannel WB. Atrial fibrillation as an independent risk factor for stroke: the Framingham Study. Stroke. 1991;22: 983-8.

6. Piccini JP, Hammill BG, Sinner MF, Hernandez AF, Walkey AJ, Benjamin EJ, et al. Clinical course of atrial fibrillation in older adults: the importance of cardiovascular events beyond stroke. Eur Heart J. 2014;35:250-6.

7. Chugh SS, Havmoeller R, Narayanan K, Singh D, Rienstra M, Benjamin EJ, et al. Worldwide epidemiology of atrial fibrillation: 
a Global Burden of Disease 2010 Study. Circulation. 2014;129: 837-47.

8. GBD 2016 Disease and Injury Incidence and Prevalence Collaborators AA, Abate KH, Abbafati C, Abbas KM, Abd-Allah F, Abdulkader RS, et al. Global, regional, and national incidence, prevalence, and years lived with disability for 328 diseases and injuries for 195 countries, 1990-2016: a systematic analysis for the Global Burden of Disease Study 2016. Lancet. 2017;390: 1211-59.

9. Qiu C, Fratiglioni L. A major role for cardiovascular burden in agerelated cognitive decline. Nat Rev Cardiol. 2015;12:267-77.

10. Alzheimer's Disease International. World Alzheimer report 2015. London: Alzheimer's Disease International; 2015.

11. Wortmann M. Dementia: a global health priority - highlights from an ADI and World Health Organization report. Alzheimers Res Ther. 2012;4:40.

12. Alzheimer's Disease International (ADI). Policy brief for G8 heads of government. The global impact of dementia 2013-2050. London: ADI; 2013.

13.• Dagres N, Chao T-F, Fenelon G, Aguinaga L, Benhayon D, Benjamin EJ, et al. European Heart Rhythm Association (EHRA)/Heart Rhythm Society (HRS)/Asia Pacific Heart Rhythm Society (APHRS)/Latin American Heart Rhythm Society (LAHRS) expert consensus on arrhythmias and cognitive function: what is the best practice? Europace 2018. doi:https://doi.org/10. 1093/europace/euy046. A comprehensive expert consensus on arrhtymia and cognitive function with detailed literature review on the impact of different types of arrhythmias on cognitive function, as well as implications for furtuer research and clinical practice regarding prevention and treatment strategies.

14. Nishtala A, Piers RJ, Himali JJ, Beiser AS, Davis-Plourde KL, Saczynski JS, et al. Atrial fibrillation and cognitive decline in the Framingham Heart Study. Hear Rhythm. 2018;15:166-72.

15.• Chen LY, Norby FL, Gottesman RF, Mosley TH, Soliman EZ, Agarwal SK, et al. Association of atrial fibrillation with cognitive decline and dementia over 20 years: the ARIC-NCS (Atherosclerosis Risk in Communities Neurocognitive Study). J Am Heart Assoc. 2018;7:e007301. A large longitudinal population-based study showed that $\mathrm{AF}$ is associated with greater cognitive decline and higher risk of dementia, independent of ischemic stroke.

16. Singh-Manoux A, Fayosse A, Sabia S, Canonico M, Bobak M, Elbaz A, et al. Atrial fibrillation as a risk factor for cognitive decline and dementia. Eur Heart J 2017;38:2612-2618. A large longitudinal population-based study that showed that longer exposure to AF was associated with faster cognitive decline, independent of incident stroke.

17.• de Bruijn RF, Heeringa J, Wolters FJ, Franco OH, Stricker BHC, Hofman A, et al. Association between atrial fibrillation and dementia in the general population. JAMA Neurol. 2015;72:1288-94. A large longitudinal population-based study that demonstrated a higher dementia risk associated with AF only among participants younger than 67 years

18. Rusanen M, Kivipelto M, Levälahti E, Laatikainen T, Tuomilehto J, Soininen $\mathrm{H}$, et al. Heart diseases and long-term risk of dementia and Alzheimer's disease: a population-based CAIDE study. J Alzheimers Dis. 2014;42:183-91.

19. Thacker EL, McKnight B, Psaty BM, Longstreth WT, Sitlani CM, Dublin S, et al. Atrial fibrillation and cognitive decline: a longitudinal cohort study. Neurology. 2013;81:119-25.

20. Haring B, Leng X, Robinson J, Johnson KC, Jackson RD, Beyth R, et al. Cardiovascular disease and cognitive decline in postmenopausal women: results from the Women's Health Initiative Memory Study. J Am Heart Assoc. 2013;2:e000369.
21. Marzona I, O'Donnell M, Teo K, Gao P, Anderson C, Bosch J, et al. Increased risk of cognitive and functional decline in patients with atrial fibrillation: results of the ONTARGET and TRANSCEND studies. Can Med Assoc J. 2012;184:e329-36.

22. Dublin S, Anderson ML, Haneuse SJ, Heckbert SR, Crane PK, Breitner JCS, et al. Atrial fibrillation and risk of dementia: a prospective cohort study. J Am Geriatr Soc. 2011;59:1369-75.

23. Marengoni A, Qiu C, Winblad B, Fratiglioni L. Atrial fibrillation, stroke and dementia in the very old: a population-based study. Neurobiol Aging. 2011;32:1336-7.

24. Bunch TJ, Weiss JP, Crandall BG, May HT, Bair TL, Osborn JS, et al. Atrial fibrillation is independently associated with senile, vascular, and Alzheimer's dementia. Hear Rhythm. 2010;7:433-7.

25. Peters R, Poulter R, Beckett N, Forette F, Fagard R, Potter J, et al. Cardiovascular and biochemical risk factors for incident dementia in the hypertension in the very elderly trial. J Hypertens. 2009;27: 2055-62.

26. Rastas S, Verkkoniemi A, Polvikoski T, Juva K, Niinistö L, Mattila $\mathrm{K}$, et al. Atrial fibrillation, stroke, and cognition: a longitudinal population-based study of people aged 85 and older. Stroke. 2007;38:1454-60.

27. Tilvis RS, Kähönen-Väre MH, Jolkkonen J, Valvanne J, Pitkala KH, Strandberg TE. Predictors of cognitive decline and mortality of aged people over a 10-year period. J Gerontol A Biol Sci Med Sci. 2004;59:268-74.

28. Proietti M, Recchia A, Riva E, Lucca U, Tettamanti M, Mannucci PM, et al. Relationship between atrial fibrillation and cognitive decline in individuals aged 80 and older. Eur J Intern Med. 2017;46:6-10. The first review that solely focused on the association between $\mathrm{AF}$ and dementia in very old people ( $\geq 80$ years) and found no reliable evidence supporting an association between $\mathrm{AF}$ and increased risk of dementia in the very old.

29. Kwok CS, Loke YK, Hale R, Potter JF, Myint PK. Atrial fibrillation and incidence of dementia: a systematic review and meta-analysis. Neurology. 2011;76:914-22.

30. Santangeli P, Di Biase L, Bai R, Mohanty S, Pump A, Cereceda Brantes M, et al. Atrial fibrillation and the risk of incident dementia: a meta-analysis. Hear Rhythm. 2012;9:1761-8.

31. Kalantarian S, Stern TA, Mansour M, Ruskin JN. Cognitive impairment associated with atrial fibrillation. Ann Intern Med. 2013;158: 338-46.

32. Dietzel J, Haeusler KG, Endres M. Does atrial fibrillation cause cognitive decline and dementia? Europace. 2018;20:408-19.

33. Lau DH, Nattel S, Kalman JM, Sanders P. Modifiable risk factors and atrial fibrillation. Circulation. 2017;136:583-96.

34. Kalantarian S, Ruskin JN. Atrial fibrillation and cognitive decline. Cardiol Clin. 2016;34:279-85.

35. Aldrugh S, Sardana M, Henninger N, Saczynski JS, McManus DD. Atrial fibrillation, cognition and dementia: a review. J Cardiovasc Electrophysiol. 2017;28:958-65.

36. Rivard L, Khairy P. Mechanisms, clinical significance, and prevention of cognitive impairment in patients with atrial fibrillation. Can J Cardiol. 2017;33:1556-64.

37. Bell RD, Zlokovic BV. Neurovascular mechanisms and blood-brain barrier disorder in Alzheimer's disease. Acta Neuropathol. 2009;118:103-13.

38. DeSimone CV, Graff-Radford J, El-Harasis MA, Rabinstein AA, Asirvatham SJ, Holmes DR. Cerebral amyloid angiopathy. J Am Coll Cardiol. 2017;70:1173-82.

39. Ihara M, Washida K. Linking atrial fibrillation with Alzheimer's disease: epidemiological, pathological, and mechanistic evidence. J Alzheimers Dis. 2018;62:61-72.

40. Alosco ML, Spitznagel MB, Sweet LH, Josephson R, Hughes J, Gunstad J. Atrial fibrillation exacerbates cognitive dysfunction and cerebral perfusion in heart failure. Pacing Clin Electrophysiol. 2015;38:178-86. 
41. Guo Y, Lip GYH, Apostolakis S. Inflammation in atrial fibrillation. J Am Coll Cardiol. 2012;60:2263-70.

42. Issac TT, Dokainish H, Lakkis NM. Role of inflammation in initiation and perpetuation of atrial fibrillation. J Am Coll Cardiol. 2007;50:2021-8.

43. Friedrichs K, Klinke A, Baldus S. Inflammatory pathways underlying atrial fibrillation. Trends Mol Med. 2011;17:556-63.

44. Hu Y-F, Chen Y-J, Lin Y-J, Chen S-A. Inflammation and the pathogenesis of atrial fibrillation. Nat Rev Cardiol. 2015;12:230-43.

45. Takeda S, Sato N, Morishita R. Systemic inflammation, blood-brain barrier vulnerability and cognitive/non-cognitive symptoms in Alzheimer disease: relevance to pathogenesis and therapy. Front Aging Neurosci. 2014;6:171.

46. Wersching H, Duning T, Lohmann H, Mohammadi S, Stehling C, Fobker M, et al. Serum C-reactive protein is linked to cerebral microstructural integrity and cognitive function. Neurology. 2010;74:1022-9.

47. Schmidt R, Schmidt H, Curb JD, Masaki K, White LR, Launer LJ. Early inflammation and dementia: a 25-year follow-up of the Honolulu-Asia Aging Study. Ann Neurol. 2002;52:168-74.

48. Pantoni L. Cerebral small vessel disease: from pathogenesis and clinical characteristics to therapeutic challenges. Lancet Neurol. 2010;9:689-701.

49. Shi Y, Wardlaw JM. Update on cerebral small vessel disease: a dynamic whole-brain disease. Stroke Vasc Neurol. 2016;1:83-92.

50. Wardlaw JM, Smith EE, Biessels GJ, Cordonnier C, Fazekas F, Frayne R, et al. Neuroimaging standards for research into small vessel disease and its contribution to ageing and neurodegeneration. Lancet Neurol. 2013;12:822-38.

51. Ding J, Sigurðsson S, Jónsson PV, Eiriksdottir G, Charidimou A, Lopez OL, et al. Large perivascular spaces visible on magnetic resonance imaging, cerebral small vessel disease progression, and risk of dementia: the Age, Gene/Environment SusceptibilityReykjavik Study. JAMA Neurol. 2017;74:1105-12.

52. Kalantarian S, Ay H, Gollub RL, Lee H, Retzepi K, Mansour M, et al. Association between atrial fibrillation and silent cerebral infarctions: a systematic review and meta-analysis. Ann Intern Med. 2014;161:650-8.

53. Vermeer SE, Hollander M, van Dijk EJ, Hofman A, Koudstaal PJ, Breteler MMB, et al. Silent brain infarcts and white matter lesions increase stroke risk in the general population: the Rotterdam Scan Study. Stroke. 2003;34:1126-9.

54. Vermeer SE, Prins ND, den Heijer T, Hofman A, Koudstaal PJ, Breteler MMB. Silent brain infarcts and the risk of dementia and cognitive decline. N Engl J Med. 2003;348:1215-22.

55. Chen LY, Lopez FL, Gottesman RF, Huxley RR, Agarwal SK, Loehr L, et al. Atrial fibrillation and cognitive decline-the role of subclinical cerebral infarcts: the atherosclerosis risk in communities study. Stroke. 2014;45:2568-74.

56. Mayasi Y, Helenius J, McManus DD, Goddeau RP, Jun-O'Connell $\mathrm{AH}$, Moonis M, et al. Atrial fibrillation is associated with anterior predominant white matter lesions in patients presenting with embolic stroke. J Neurol Neurosurg Psychiatry. 2018;89:6-13. A small register-based study that showed that $\mathrm{AF}$ was associated with anterior subcortical white matter hyperintensity, which suggests that the link between AF and brain injuries goes beyond thromboembolic mechanisms.

57. Kobayashi A, Iguchi M, Shimizu S, Uchiyama S. Silent cerebral infarcts and cerebral white matter lesions in patients with nonvalvular atrial fibrillation. J Stroke Cerebrovasc Dis. 2012;21: 310-7.

58. Piers RJ, Nishtala A, Preis SR, DeCarli C, Wolf PA, Benjamin EJ, et al. Association between atrial fibrillation and volumetric magnetic resonance imaging brain measures: Framingham Offspring Study. Hear Rhythm. 2016;13:2020-4.
59. Goldberg I, Auriel E, Russell D, Korczyn AD. Microembolism, silent brain infarcts and dementia. J Neurol Sci. 2012;322:250-3.

60. Debette S, Markus HS. The clinical importance of white matter hyperintensities on brain magnetic resonance imaging: systematic review and meta-analysis. BMJ. 2010;341:c3666.

61. Thong JYJ, Hilal S, Wang Y, Soon HW, Dong Y, Collinson SL, et al. Association of silent lacunar infarct with brain atrophy and cognitive impairment. J Neurol Neurosurg Psychiatry. 2013;84:121925.

62. Payabvash S, Souza LCS, Wang Y, Schaefer PW, Furie KL, Halpern EF, et al. Regional ischemic vulnerability of the brain to hypoperfusion: the need for location specific computed tomography perfusion thresholds in acute stroke patients. Stroke. 2011;42: 1255-60.

63. Yates PA, Villemagne VL, Ellis KA, Desmond PM, Masters CL, Rowe CC. Cerebral microbleeds: a review of clinical, genetic, and neuroimaging associations. Front Neurol. 2014;4:205.

64. Knecht S, Oelschläger C, Duning T, Lohmann H, Albers J, Stehling $\mathrm{C}$, et al. Atrial fibrillation in stroke-free patients is associated with memory impairment and hippocampal atrophy. Eur Heart J. 2008;29:2125-32.

65. Stefansdottir H, Arnar DO, Aspelund T, Sigurdsson S, Jonsdottir $\mathrm{MK}, \mathrm{Hjaltason} \mathrm{H}$, et al. Atrial fibrillation is associated with reduced brain volume and cognitive function independent of cerebral infarcts. Stroke. 2013;44:1020-5.

66. Saito T, Kawamura Y, Tanabe Y, Asanome A, Takahashi K, Sawada $\mathrm{J}$, et al. Cerebral microbleeds and asymptomatic cerebral infarctions in patients with atrial fibrillation. J Stroke Cerebrovasc Dis. 2014;23:1616-22.

67. Diener H-C, Selim MH, Molina CA, Greenberg SM. Embolic stroke, atrial fibrillation, and microbleeds. Stroke. 2016;47:904-7.

68. Song T-J, Kim J, Lee HS, Nam CM, Nam HS, Heo JH, et al. The frequency of cerebral microbleeds increases with CHADS(2) scores in stroke patients with non-valvular atrial fibrillation. Eur J Neurol. 2013;20:502-8.

69. Akoudad S, Wolters FJ, Viswanathan A, de Bruijn RF, van der Lugt A, Hofman A, et al. Association of cerebral microbleeds with cognitive decline and dementia. JAMA Neurol. 2016;73:934-43.

70. Camm AJ, Lip GYH, De Caterina R, Savelieva I, Atar D, Hohnloser SH, et al. 2012 focused update of the ESC Guidelines for the management of atrial fibrillation. Developed with the special contribution of the European Heart Rhythm Association. Eur Heart J. 2012;33:2719-47.

71. Jacobs V, Cutler MJ, Day JD, Bunch TJ. Atrial fibrillation and dementia. Trends Cardiovasc Med. 2015;25:44-51.

72. Hui DS, Morley JE, Mikolajczak PC, Lee R. Atrial fibrillation: a major risk factor for cognitive decline. Am Heart J. 2015;169:448 56.

73. Poggesi A, Inzitari D, Pantoni L. Atrial fibrillation and cognition: epidemiological data and possible mechanisms. Stroke. 2015;46: 3316-21.

74. Lip GYH, Laroche C, Dan G-A, Santini M, Kalarus Z, Rasmussen LH, et al. "Real-world" antithrombotic treatment in atrial fibrillation: the EORP-AF pilot survey. Am J Med. 2014;127:519-529.e1.

75. Moffitt P, Lane DA, Park H, O'Connell J, Quinn TJ. Thromboprophylaxis in atrial fibrillation and association with cognitive decline: systematic review. Age Ageing 2016;45:767-75. A meta-analysis that explored the cognitive effect of AF thromboprophylaxis and showed no definitive evidence of protective or harmful effect of anticoagulant drugs on cognitive function in $\mathbf{A F}$ patients.

76.• Friberg L, Rosenqvist M. Less dementia with oral anticoagulation in atrial fibrillation. Eur Heart J. 2018;39:453-60. A large retrospective register-based study that showed that the risk of dementia was $29 \%$ lower in AF patients on anticoagulant treatment than those who did not use anticoagulant drugs. 
77. Madhavan M, Hu TY, Gersh BJ, Roger VL, Killian J, Weston SA, Graff-Radford J, Asirvatham SJ, Chamberlain AM Efficacy of warfarin anticoagulation and incident dementia in a community-based cohort of atrial fibrillation. Mayo Clin Proc 2018;93:145-54. A community-based study that demonstrated that warfarin therapy was associated with $20 \%$ reduction in the risk of dementia in patients with $\mathbf{A F}$.

78. Jacobs V, May HT, Bair TL, Crandall BG, Cutler MJ, Day JD, et al. Long-term population-based cerebral ischemic event and cognitive outcomes of direct oral anticoagulants compared with warfarin among long-term anticoagulated patients for atrial fibrillation. Am J Cardiol 2016;118:210-4. A community-based study that showed that use of noval oral anticoagulant drugs was associated with a reduced risk of cerebral ischemic events and newonset dementia compared to warfarin.

79. Cheng W, Liu W, Li B, Li D. Relationship of anticoagulant therapy with cognitive impairment among patients with atrial fibrillation. J Cardiovasc Pharmacol. 2018;71:380-7.

80. Flaker GC, Pogue J, Yusuf S, Pfeffer MA, Goldhaber SZ, Granger $\mathrm{CB}$, et al. Cognitive function and anticoagulation control in patients with atrial fibrillation. Circ Cardiovasc Qual Outcomes. 2010;3: 277-83.

81. Jacobs V, Woller SC, Stevens S, May HT, Bair TL, Anderson JL, et al. Time outside of therapeutic range in atrial fibrillation patients is associated with long-term risk of dementia. Hear Rhythm. 2014;11: 2206-13.

82. Giugliano RP, Ruff CT, Braunwald E, Murphy SA, Wiviott SD, Halperin JL, et al. Edoxaban versus warfarin in patients with atrial fibrillation. N Engl J Med. 2013;369:2093-104.

83. Granger CB, Alexander JH, McMurray JJV, Lopes RD, Hylek EM, Hanna M, et al. Apixaban versus warfarin in patients with atrial fibrillation. N Engl J Med. 2011;365:981-92.
84. Bartolucci AA, Tendera M, Howard G. Meta-analysis of multiple primary prevention trials of cardiovascular events using aspirin. Am J Cardiol. 2011;107:1796-801.

85. Lip GYH. The role of aspirin for stroke prevention in atrial fibrillation. Nat Rev Cardiol. 2011;8:602-6.

86. Veronese N, Stubbs B, Maggi S, Thompson T, Schofield P, Muller C, et al. Low-dose aspirin use and cognitive function in older age: a systematic review and meta-analysis. J Am Geriatr Soc. 2017;65:1763-8.

87. Albert MA, Danielson E, Rifai N, Ridker PM. For the PRINCE investigators. Effect of statin therapy on C-reactive protein levels. JAMA. 2001;286:64-70.

88. Chao T-F, Liu C-J, Chen S-J, Wang K-L, \, Chang S-L, et al. Statins and the risk of dementia in patients with atrial fibrillation: a nationwide population-based cohort study. Int J Cardiol 2015;196:91-97. A large register-based study that showed that use of statin was associated with lower risk of non-vascular dementia.

89. Lappegård KT, Pop-Purceleanu $\mathrm{M}$, van Heerde W, Sexton J, Tendolkar I, Pop G. Improved neurocognitive functions correlate with reduced inflammatory burden in atrial fibrillation patients treated with intensive cholesterol lowering therapy. J Neuroinflammation. 2013;10:844.

90. Chung MK, Shemanski L, Sherman DG, Greene HL, Hogan DB, Kellen JC, et al. Functional status in rate- versus rhythm-control strategies for atrial fibrillation: results of the Atrial Fibrillation Follow-Up Investigation of Rhythm Management (AFFIRM) Functional Status Substudy. J Am Coll Cardiol. 2005;46:1891-9.

91. Bunch TJ, Crandall BG, Weiss JP, May HT, Bair TL, Osborn JS, et al. Patients treated with catheter ablation for atrial fibrillation have long-term rates of death, stroke, and dementia similar to patients without atrial fibrillation. J Cardiovasc Electrophysiol. 2011;22: 839-45. 